\title{
Downscaling Rainfall in Benin: A Deltaic City of the Niger Delta Region, under two Emission Scenarios
}

\author{
M. B. T. Kpang \\ Dept. of Geography and Environmental Management, University of Port Harcourt \\ PMB 5323, Port Harcourt, Nigeria \\ M. O. Nwagbara \\ Dept. of Geography and Environmental Management, University of Port Harcourt \\ PMB 5323, Port Harcourt, Nigeria
}

Received: October 18, 2018 Accepted: November 9, 2018 Published: November 27, 2018

doi:10.5296/emsd.v7i4.13972ＵRL: https://doi.org/10.5296/emsd.v7i4.13972

\begin{abstract}
This study endeavored to downscale rainfall in Benin City so as to reveal what pathway would be more tolerable in the metropolis both now and in the future, putting the current effect of rainfall in the area in mind. Quasi-experimental research design was adopted and data for rainfall (1985-2015) was collected from the archive of the Nigerian meteorological agency (NIMET). While data of large scale predictors were collected from the HadCM3 data achieve. Calibration period was from 1985 to 2001, while validation was 2001 to 2015 . Analysis of variance was used to trace if there was a significant difference in the temporal rainfall characteristics for $\mathrm{A} 2$ and $\mathrm{B} 2$ emission scenarios. However the study found that the predictors that explain rainfall patterns in the area were Shum, Rhum, R850 and R500; and during calibration it was found that rainfall significantly depended on these predictors at $\mathrm{P}<0.05$. However, during validation, statistics show that the models performed considerably well in which case the modeled data related well with the observed data for all seasons of the year i.e. DJF season $r-0.92\left(\mathrm{r}^{2}-0.85\right.$; RMSE 0.31; RSD, 0.89) at $\mathrm{P}<0.05$; MAM r-0.81 $\left(\mathrm{r}^{2}-0.66\right.$; RMSE 0.41; RSD, 0.91) at $\mathrm{P}<0.05$; JJA r-0.76 ( $\mathrm{r}^{2}-0.58$; RMSE 0.31; RSD, 0.97) at $\mathrm{P}<0.05$; SON r-0.82 ( $\mathrm{r}^{2}-0.67$; RMSE 0.26; RSD, 0.82) at $\mathrm{P}<0.05$. However there are some uncertainties in the data set for which caution must be taken while relying on the out puts of the model of the current study. As a result, the study recommends the use of clean technology, and a development of flood risk preparedness to deal with flood effects as a result increasing amounts of rainfall in the metropolis amongst others.
\end{abstract}


Keywords: Downscaling, Rainfall, Benin, Niger-Delta region

\section{Introduction}

In recent times rainfall discussion due to increasing warming of the earth surface (global warming) and global climate change have been a major issues of discuss. This is because not only do human lives depend on the climate system for existence; many sectors of the global economy also depend on it. For example Samuels (2006) has expressed that if rainfall continues to raise unabated severe consequences will arise for plants and animals, social systems, and even humans. This projected change in human and natural system resulting from rainfall is said to be with more repercussion for the developing nations of the world (Ozabor \& Nwagbara, 2018). This is because, advances in technology, has been so slow or in some cases retrogressive. Yet rather than develop a means of coping with the consequences that results from rainfall, developmental strides are still poisonous to the atmosphere (via the introduction of gasses that will impact the atmosphere negatively, such as the release of $\mathrm{CH}_{4}$, $\mathrm{CO}_{2}, \mathrm{CFCs}$ ). Therefore as greenhouse gases increase, ozone layer is depleted and temperature rises with pervasive effects on the cloud formation and the subsequent rainfall. This idea of global rainfall change in volumes and intensities has also been reported by IPCC (2007) that rainfall departures already rose by some millimetres, within the industrial revolution era and that this rising rainfall amount will possibly lead to severe displacements around 2100 (IPCC, 2014) due to flooding incidents; especially around coastal environments.

Therefore, the fear of what this rainfall rise is going to do to humans and natural systems have led to the development of GCMs by several working groups of the IPCC. General circulation models are mathematical models used to explain the dynamics of the weather and climate systems and therefrom make projections into the future. However, the resolutions at which these GCMs are coupled are too coarse hence the need to downscale. Downscaling, refers to finding a mathematical link between the large scale predictors and the predictand (s) (local weather elements).

Downscaling can be done in the following two ways; dynamical (DD) and statistical (SD) (Christensen et al., 2007; Fowler et al., 2007). Whereas statistical relationships between large-scale GCM/weather information and predictands (local weather variables) is sort in statistical downscaling (Hewitson and Crane 1996; Wilby et al. 2004),Dynamic downscaling uses regional climate models (RCMs) for limited regions with boundary conditions from GCM simulations (Sayad, Ali, \& Kamel, 2016). However, Wilby et al. (2002) have expressed that both the statistical downscaling and the dynamic downscaling methods have their advantage and disadvantages. Other researchers have suggested that the dynamic downscaling may be too expensive to operationalize, especially in the case of self-funded researches (Cubasch et al.,1996; Timbal et al., 2003; Wilby et al., 2004; Wood et al., 2004; B'ardossy and Plate,1992; von Storch et al., 1993; Wilby et al., 1998a,b; Zorita and von Storch, 1999; Beckmann and Buishand, 2002, Karl et al., 1990; Busuioc et al., 2001; Christensen et al., 2007; Fowler et al., 2007).

Nevertheless, with all the works on downscaling that has been done to access the impacts climate will have on people in the future in the developed world, minimal works have been 
done in Nigeria and elsewhere in the developing world. This in itself, and other factors have probably led to the nonchalant attitude of inhabitants of the developing world. Who are consistently, increasing the amount of GHGs they emit into the atmosphere through anthropogenic activities and asking why the weather (rainfall) is changing. The case in Benin City is not different, rapid urban expansion, deforestation, ineffective transportation means/modes, burning of fossil fuels into the atmosphere etc. have gradually increased the rainfall amounts and also altered other weather elements. Obviously, there have been several researches (Omogbai, 1985; Omere, 2001; Efe, \& Eyefia, 2014) on rainfall in Benin City but none have used the downscaling technique nor projected the rainfall of the place using the two scenarios presented in the HadCM3 GCM. This study is thus set to carry out this study in Benin City with this lacuna in focus.

\section{Materials and Methods}

Benin City is the capital city of Edo State, Nigeria which is located in the South-South geopolitical zone of Nigeria. It is bounded by Latitude $6^{\circ} 06^{\prime} \mathrm{N}$ and - Longitude $5^{\circ} 30^{\prime} \mathrm{E}$ and the total area is about 500sq.km. The area falls within the tropical environment that enjoys the tropical rain forest climate of Koppen's (1981) and the west equatorial climate of Strahler (2002). The climate of Benin City is influenced by two principal air masses, namely, Tropical Maritime Air-mass (mT) and Tropical Continental Air-mass (cT). These two air masses determine the seasons of the area, which are the wet and dry seasons respectively (Bello, 2009, Ozabor, 2010). The Tropical Maritime Airmass prevails mainly from April to September (Benin Airport Weather Report, 2009). The Tropical Continental Air Mass by contrast prevails from October to February, there by bringing in the dry season and harmattan season in Benin City and Environs (Bello, 2009). However, Ozabor (2014), had stressed that these demarcation of dry and rainy seasons are almost unidentifiable by climatological standards. Besides these two seasons, the area also experiences the August break or what is also known as the August hiatus, which usually occurs in the second to fourth week of August. However there may be temporary or interrupted showers during this period (Benin Airport Weather Report, 2009). The vegetation of the area varies from swamp forest in the South Western part, to the rain forest in the middle, then Savannah in the North (Iloje, 1980; Odemerho, 1984; Areola, 1980; Iwenna, 2000). In the area where the original forests exist, there are tall trees, some of which shed their leaves during the dry season. In the area where deforestation has occurred, elephant grasses colonize them. The Benin low lands have been covered with vast Rain forest, but rubber forest especially in the past, while the Esan Plateau is made up of diverse vegetation, which include Savannah in the North and Rain Forest in the South. The riverine communities in the South have been mainly mangrove swamp vegetation (Bellow, 2009). However more recently the following factors have been listed as factors responsible for the modification of the climate of the area: alteration in speed and circulation of air-masses, human activities such as clearing of natural vegetation and replacing them with industries, buildings and others such as agricultural events (Ozabor and Obisesan, 2015). Other factors are increase in population of rivers and the use of generators, fairly used motor cycles and vehicles, these automobiles release fumes into the atmosphere, thereby modifying the weather conditions of the area (Bello, 2009). 


\section{\لMacrothink}

In terms of methods the study adopted the quasi-experimental research design. As such data for rainfall (daily scale) for the period 1985-2015 was collected from the archive of the Nigerian meteorological agency (NIMET). While data of large scale predictors were collected from the HadCM3 data achieve. To be able to select the HadCM3 grid box that matched that of Benin City, the HadCM3 grid boxes were first superimposed on the map of Nigeria and as such the position of Benin within the spatial map was revealed (cell 3,31 of the HadCM3), hence the data in that box was downloaded from same box. After data collection, variables were screened in the SDSM environment as such the predictors (see table 1) that correlated highly with the predictand, were selected to calibrate the model. Calibration period was from 1985 to 2001, while validation was 2001 to 2015. The data after validation was synthesized with the NCEP predictors and assembles of 20 loadings was generated and the corresponding rainfall for 139 years was derived (1960-2099) using two scenarios (A2 and B2 scenarios) available in HadCM3 data bank were used to explain the past and future rainfall outcomes of the area under review for 1960-2075. Furthermore, the analysis of variance was used to trace if there was a significant difference in the temporal rainfall characteristics. However, the ANOVA analysis was done in the SPSS environment.

Table 1. List of NCEP predictors used in the screening process

\begin{tabular}{|l|l|l|l|l|l|l|}
\hline S/N & Predictor & Description & S/N & Predictor & Description \\
\hline \multicolumn{5}{|c|}{ Code } & \multicolumn{2}{|c|}{ Code } \\
\hline 1 & p_f & Surface airflow strength & 14 & r500 & $500 \mathrm{hPa}$ relative humidity \\
\hline 2 & p_u & Surface zonal velocity & 15 & $\mathrm{p} 8 \_\mathrm{f}$ & $850 \mathrm{hPa}$ airflow strength \\
\hline 3 & p_v & Surface meridional velocity & 16 & $\mathrm{p} 8 \_\mathrm{u}$ & $850 \mathrm{hPa}$ zonal velocity \\
\hline 4 & p_z & Surface vorticity & 17 & $\mathrm{p} 8 \_\mathrm{v}$ & $850 \mathrm{hPa}$ meridional velocity \\
\hline 5 & p_th & Surface wind direction & 18 & $\mathrm{p} 8 \_\mathrm{z}$ & $850 \mathrm{hPa}$ vorticity \\
\hline 6 & p_zh & Surface divergence & 19 & $\mathrm{p} 8 \mathrm{th}$ & $850 \mathrm{hPa}$ wind direction \\
\hline 7 & rhum & Surface relative humidity & 20 & $\mathrm{p} 8 \mathrm{zh}$ & $850 \mathrm{hPa}$ divergence \\
\hline 8 & p5_f & $500 \mathrm{hPa}$ airflow strength & 21 & r850 & $850 \mathrm{hPa}$ relative humidity \\
\hline 9 & p5_u & $500 \mathrm{hPa}$ zonal velocity & 22 & $\mathrm{p} 500$ & $500 \mathrm{hPa}$ geopotential height \\
\hline 10 & p5_v & $500 \mathrm{hPa}$ meridional velocity & 23 & $\mathrm{p} 850$ & $850 \mathrm{hPa}$ geopotential height \\
\hline 11 & p5_z & $500 \mathrm{hPa}$ vorticity & 24 & temp & Mean temperature at 2m \\
\hline 12 & p5th & $500 \mathrm{hPa}$ wind direction & 25 & shum & Surface-specific humidity \\
\hline 13 & p5zh & $500 \mathrm{hPa}$ divergence & 26 & $\mathrm{mslp}$ & Mean sea level pressure \\
\hline
\end{tabular}

Source: NCEP Archives

\section{Results and Discussion}

In table two it is well lucid that the large scale predictors show considerable relationship with the predictand (in this case rainfall), and they were all also significant at $\mathrm{p}<0.05$. Implication is that Shum, Rhum, R850 and R500 are the predictors selected for the calibration process. Characteristically these predictors have also been identified in other studies (Busuioc, etal., 2001; Christensen etal.,2007; Sayad.,etal., 2016; Storch etal.,1999; Timbal, etal., 2003; Wilby, etal., 2004), to be the basic predictors for rainfall as a predictand in other studies. 
Table 2. Rainfall Predictors for Benin

\begin{tabular}{|l|l|l|}
\hline Predictors & R & P value at 0.05 \\
\hline Shum & 0.668 & 0.00 \\
\hline Rhum & 0.659 & 0.00 \\
\hline R850 & 0.724 & 0.00 \\
\hline R500 & 0.648 & 0.00 \\
\hline
\end{tabular}

Nevertheless, during calibration these predictors were seen to be significantly influential on the determination of rains in the area at $p<0.05$ (see table 3) the implication of this is that rainfall significantly depend on Shum, Rhum, R850 and R500 in Benin City.

Table 3. Regression Model Summary for Selected Large Scale Predictors and Predictand for Benin City. ANOVA(b)

\begin{tabular}{|l|l|l|l|l|l|l|}
\hline Model & & Sum of Squares & Df & Mean Square & F & Sig. \\
\hline 1 & Regression & 4710044.183 & 4 & 1177511.046 & 116.067 & $.000(\mathrm{a})$ \\
\hline & Residual & 4068200.959 & 5471 & 10145.140 & & \\
\hline & Total & 8778245.142 & 5474 & & & \\
\hline
\end{tabular}

a Predictors: (Constant), r500, shum, rhum, r850

b Dependent Variable: Benin_RF

However, in table 4 the validation statistics show that the models performed considerably well. In the table the modeled data related well with the observed data for all seasons of the year. For the DJF season the relationships between modeled and observed data was high at $\mathrm{r}-0.92\left(\mathrm{r}^{2}-0.85\right.$; RMSE 0.31; RSD, 0.89) at $\mathrm{P}<0.05$. For the MAM season the relationships between modeled and observed data was also high at $r-0.81\left(r^{2}-0.66\right.$; RMSE 0.41 ; RSD, 0.91) at $\mathrm{P}<0.05$. In the JJA season the relationships between modeled and observed data was also high at $\mathrm{r}-0.76\left(\mathrm{r}^{2}-0.58\right.$; RMSE 0.31 ; RSD, 0.97) at $\mathrm{P}<0.05$. The SON season, also showed high relationship between modeled and observed data at $r-0.82\left(r^{2}-0.67\right.$; RMSE 0.26; RSD, 0.82 ) at $\mathrm{P}<0.05$. The result of this validation is further confirmed by the results in table 5 , where the modeled and observed data are shown.

Table 4. Validation of SDSM for seasonal rainfall predictions

\begin{tabular}{|l|l|l|l|l|l|l|l|}
\hline Station & Scale of SDSM & Rainfall seasons & R & $\mathrm{r}^{2}$ & RMSE & RSD & P value at 0.05 \\
\hline Benin & Seasonal & DJF & 0.92 & 0.85 & 0.31 & 0.89 & 0.00 \\
& & MAM & 0.81 & 0.66 & 0.41 & 0.91 & 0.00 \\
& & JJA & 0.76 & 0.58 & 0.31 & 0.97 & 0.00 \\
& & SON & 0.82 & 0.67 & 0.26 & 0.82 & 0.00 \\
\hline
\end{tabular}

However there are some uncertainties in the data set for which caution must be taken while relying on the out puts of the model of the current study. This is clearly shown in table 5 where the Wilcoxon signed rank results show that for the A2 scenario, there is no significant relationship difference between observed and modeled data except for march, July and November which have some levels of uncertainty at $\mathrm{P}>0.05$. 


\section{Macrothink}

Table 5. Observed and modeled seasonal rainfall amounts in Benin

\begin{tabular}{|l|l|l|l|l|}
\hline Seasons & DJF & MAM & JJA & SON \\
\hline Observed rainfall in MM & 28.7 & 174.6 & 294.7 & 229.9 \\
\hline Modeled rainfall in MM & 28.3 & 170.5 & 290.5 & 229 \\
\hline
\end{tabular}

Table 6. Rainfall uncertainty analysis for Benin

\begin{tabular}{|l|l|l|}
\hline Months & A2 scenario & B2 Scenario \\
\hline January & 0.541 & 0.132 \\
\hline February & 0.311 & 0.231 \\
\hline March & 0.021 & 0.431 \\
\hline April & 0.231 & 0.021 \\
\hline May & 0.233 & 0.234 \\
\hline June & 0.231 & 0.345 \\
\hline July & 0.010 & 0.123 \\
\hline August & 0.234 & 1.231 \\
\hline September & 0.141 & 0.041 \\
\hline October & 0.342 & 2.113 \\
\hline November & 0.005 & 0.731 \\
\hline December & 0.231 & 0.278 \\
\hline
\end{tabular}

In the B2 scenario, the months of April, and September indicated some levels of uncertainty at $\mathrm{P}>0.05$. Nonetheless table 6 shows that there is a statistically significant difference in the amounts of rain realised in the A2 scenario at $\mathrm{P}<0.05$ (F-27.272). Same can be said of the B2 scenario which also showed some difference at $\mathrm{P}<0.05$. This particular result shows that there is a noticeable difference in the out puts of the modeled data.

Table 7. Temporal variation in mean rainfall of Benin under A2 and B2 scenarios

\begin{tabular}{|l|c|l|l|}
\hline \multicolumn{2}{|c|}{ A2 scenario } & \multicolumn{2}{l|}{ B2 scenario } \\
\hline F & Sig. & F & Sig. \\
\hline 27.272 & .032 & 2.272 & .044 \\
\hline
\end{tabular}

Table 8. Duncan statistics of Benin rainfall means under A2 \& B2 scenarios

\begin{tabular}{|l|l|l|l|l|l|l|l|}
\hline \multicolumn{4}{|c|}{ B2 scenario } & \multicolumn{5}{|c|}{ A2 scenario } \\
\hline \multirow{2}{*}{ Normals } & \multicolumn{2}{|l|}{ Subset for alpha $=0.05$} & \multirow{2}{*}{ Normals } & \multicolumn{3}{|c|}{ Subset for alpha $=0.05$} \\
\cline { 2 - 5 } & 1 & 2 & 3 & & 1 & 2 & 3 \\
\hline $1960-89$ & 163 & & & $1960-89$ & 179 & & \\
\hline $1990-2019$ & & 172 & & $1990-2019$ & & 182 & \\
\hline $2020-49$ & & & 173 & $2020-49$ & & & 243 \\
\hline Sig. & 1.00 & 1.00 & 1.00 & Sig. & 1.00 & 1.00 & 1.00 \\
\hline
\end{tabular}

Table 8 therefore reveals the way the differences in rainfall amounts apply per scenario. In the table the average amount of rains in the A2 scenarios are conspicuously more than those of the B2 scenario. However, in the A2 scenario the normal 1960-89 shows that average 
amount of rainfall is $173 \mathrm{~mm}$ that has risen to $182 \mathrm{~mm}$ in the second normal and at the last normal 2020-49 the average rainfall amount is $243 \mathrm{~mm}$. This is quite different from the amounts posted by the B2 scenario whose highest amount is $173 \mathrm{~mm}$ at the last normal.

Table 9. Projected increase in rainfall amounts for A2 and B2 scenarios

\begin{tabular}{|l|l|l|}
\hline & $2016-2045$ & $2045-2075$ \\
\hline A2 scenario & 15 & 8 \\
\hline B2 scenario & 10 & 1.5 \\
\hline
\end{tabular}

In table 9 the rainfall amount increase shows that the A2 scenario predicted higher amount increase than would be the case if the B2 pathway was the case.

\section{Recommendations and Conclusion}

This study attempted to downscale rainfall in Benin City so as to reveal what pathway would be more tolerable in the metropolis both now and in the future. However the study found that the predictors that explain rainfall patterns in the area were Shum, Rhum, R850 and R500; and during calibration it was found that rainfall significantly depended on these predictors at $\mathrm{P}<0.05$. However, during validation, statistics show that the models performed considerably well in which case the modeled data related well with the observed data for all seasons of the year i.e. DJF season $r-0.92\left(r^{2}-0.85\right.$; RMSE 0.31; RSD, 0.89) at $\mathrm{P}<0.05$; MAM r-0.81 $\left(\mathrm{r}^{2}-0.66\right.$; RMSE 0.41; RSD, 0.91) at $\mathrm{P}<0.05$; JJA r-0.76 ( $\mathrm{r}^{2}-0.58$; RMSE 0.31; RSD, 0.97) at $\mathrm{P}<0.05$; SON r-0.82 ( $\mathrm{r}^{2}-0.67$; RMSE 0.26; RSD, 0.82) at $\mathrm{P}<0.05$. However there are some uncertainties in the data set for which caution must be taken while relying on the out puts of the model of the current study. These uncertainties were observed in March, July and November for A2 scenario at $\mathrm{P}>0.05$ and for B2 scenario April, and September indicated some levels of uncertainty at $\mathrm{P}>0.05$. Generally, rainfall amount increased more in the A2 scenario than in the B2 scenario. This therefore suggests that there is the need to carry out the following and urgently too:

There is need to introduce and sustain the use of clean technology in the manipulation of the environment since there is evidence that perturbation caused by increased temperature have greater impacts on the hydrologic system. Furthermore, over reliance on fossil fuels and changes in landuse are leading anthropogenic sources which have led to increase in atmospheric concentration of greenhouse gases resulting in global warming and a global energy imbalance and consequently the high amount of rainfall experienced.

Nigerian Meteorological Agency (NIMET) should as a matter of responsibility not only predict but also publish monthly rainfall, hot spot and possible damages. This information should be given in time and properly disseminated in collaboration with other agencies like National Orientation Agency (NOA) and National Emergency Management Agency (NEMA).

The state should develop flood risk preparedness to deal with flood effects as a result increasing amounts of rainfall in the metropolis. 


\section{References}

Beckmann, B. R., \& Buishand, T. A. (2002). Downscaling relationships for precipitation for the Netherlands and North Germany. International Journal of Climatology, 22, 15-32.

https://doi.org/10.1002/joc.718

Bello, E. E. (2009). The Effects of Weather Aviation in Benin Airport. Edo State. Unpublished B.Sc Project Submitted to the Department of Geography and Regional Planning. Delta State University, Abraka.

Benin Airport (2009). Weather Report, Benin City Edo State.

Busuioc, A., Chen, D., \& Hellstr"om, C. (2001). Performance of statistical downscaling models in GCM validation and regional climate change estimates: application for Swedish precipitation. International journal of Climatology, 21, 557-578.

https://doi.org/10.1002/joc.624

Christensen, J. H., Hewitson, B., Busuioc, A., Chen, A., Gao, X., Held, I., ... Whetton, P. (2007). Regional climate projections. Climate Change 2007: The Physical Science Basis, Contribution of Working Group I to the Fourth Assessment Report of the Intergovernmental Panel on Climate Change. Cambridge University Press: Cambridge.

Cubasch, U., von Storch, H., Waszkewitz, J., \& Zorita, E. (1996). Estimates of climate change in Southern Europe derived from dynamical climate model output. Climate Research, 7, 129-149. https://doi.org/10.3354/cr007129

Efe, S. I., \& Eyefia, O. A. (2014). Urban Warming in Benin City, Nigeria. Atmospheric and Climate Sciences, 4, 241-252. https://doi.org/10.4236/acs.2014.42027

Fowler, H. J., Blenkinsop, S., \& Tebaldi, C. (2007). Linking climate modeling to impacts studies: recent advances in downscaling techniques for hydrological modeling. International journal of Climatology, 27, 1547-1578. https://doi.org/10.1002/joc.1556

Hewitson, B. C., \& Crane, R. (1996). Climate downscaling: techniques and application. Clim Res, 7(2), 85-95. https://doi.org/10.3354/cr007085

Iloeje, N. P. (1980). A New Geography of West Africa. Longmann Grays Nigeria.

IPCC (2007). Climate change 2007 the physical science basis, contribution of working Group I to the fourth assessment report of the intergovernmental panel on climate change. Cambridge University Press, Cambridge, UK, and New York, USA.

Iwenna, O. A. (2000). Essential Geography for Secondary Schools; University of Benin Press, Benin City.

Karl, T. R., Wang, W. C., Schlesinger, M. E., Knight, R. W., \& Portman, D. (1990). A method of relating general circulation model simulated climate to observed local climate. Part I: seasonal statistics. Journal of Climate, 3, 1053-1079.

https://doi.org/10.1175/1520-0442(1990)003<1053:AMORGC>2.0.CO;2 
Odemerho, F. O. (1984). The Effects of Shifting Cultivation on Stream Channel Size and Hydraulic Geometry in Small Headwater Basins of Southwestern Nigeria. Geografiska Annaler. Series A, Physical Geography, 66(4), 327-340.

https://doi.org/10.1080/04353676.1984.11880119

Omere, O. O. (2001). Aspect of Urban Climate: A Case Study of Benin City. B.Sc project, Department of Geography and Regional Planning, Delta State University, Abraka.

Omogbai, B. E. (1985). Aspects of Urban Climate of Benin City. M.Sc. Dissertation, University of Ibadan, Ibadan.

Ozabor, F. (2010). Decongesting the city for effective development. Unpublished BSc project submitted to the department of Geography and regional planning, Delta state University, Abraka

Ozabor, F. (2014). Analysis of rainfall regimes in Nigeria. Unpublished MSc Dissertation submitted to the department of Geography and regional planning, Delta state University, Abraka

Ozabor, F., \& Obisesan, A. (2015). Spatio-Temporal Variation in Rainfall over South-Western Nigeria. Journal of Environmental Sciences and Resources Management, 7(2).

Samuels, R. (2006) Inadvertent Urban-Climate, Emitters, Internal-Combustion Engines and Air-Conditioners. Ecocity, 6, 1-9.

Sayad., T. A., Ali, A. M., \& Kamel, A. M. (2016). Study the Impact of Climate Change on Maximum and Minimum Temperature over Alexandria, Egypt, Using Statistical Downscaling Model (SDSM). Global Journal of Advanced Research, 3(8), 694-712.

Storch, V. H., \& Zorita, E. (1999). The analog method as a simple statistical downscaling technique: Comparison with more complicated methods. Journal of Climate, 12, 2474-2489. https://doi.org/10.1175/1520-0442(1999)012<2474:TAMAAS>2.0.CO;2

Timbal, B., Dufour, A., \& McAvaney, B. (2003). An estimate of future climate change for western France using a statistical downscaling technique. Climate Dynamics, 20, 807-823. https://doi.org/10.1007/s00382-002-0298-9

Wilby, R. L., Charles, S. P., Zorita, E., Timbal, B., Whetton, P., \& Mearns, L. O. (2004) Guidelines for use of climate scenarios developed from statistical downscaling methods. Supporting material to the Intergovernmental Panel on Climate Change, 27.

Wilby, R. L., Dawson, C. W., \& Barrow, E. M. (2002). SDSM-a decision support tool for the assessment of regional climate change impacts. Environ Modell Softw, 17(2), 145-157. https://doi.org/10.1016/S1364-8152(01)00060-3

Wood, A. W., Leung, L. R., Sridhar, V., \& Lettenmaier, D. P. (2004). Hydrologic implications of dynamical and statistical approaches to downscaling climate model outputs. Climatic Change, 62, 189-216. https://doi.org/10.1023/B:CLIM.0000013685.99609.9e 


\section{Macrothink \\ Environmental Management and Sustainable Development \\ ISSN 2164-7682}

\section{Copyright Disclaimer}

Copyright for this article is retained by the author(s), with first publication rights granted to the journal.

This is an open-access article distributed under the terms and conditions of the Creative Commons Attribution license (http://creativecommons.org/licenses/by/3.0/). 